\title{
Climate change impact on hydrological characteristics and water availability of the Mountain Pamir Rivers
}

\author{
Inom Normatov ${ }^{1}$ and Parviz Normatov ${ }^{2}$ \\ ${ }^{1}$ Meteorology and Climatology Department, Tajik National University, Dushanbe, Tajikistan \\ ${ }^{2}$ Institute of Water Problems, Hydropower and Ecology Academy of Sciences Republic of Tajikistan, \\ Dushanbe, Tajikistan
}

Correspondence: Inom Normatov (inomnor@gmail.com)

Published: 16 September 2020

\begin{abstract}
Results of monitoring accumulated snow cover in upstream areas of the Transboundary Pyanj River (Central Asia) are presented. It is found that the formation of the snow cover and the spatial distribution of atmospheric precipitation in the Mountain Pamir is determined by the orography of the terrain. Orography influences air mass movement in mountain areas, which contributes in different climatic zones to a shift in periods when the maximum amount of snow is falling. Completely different scenarios for the development of meteorological variables in the western and eastern parts of the Gunt River Basin were found, due, firstly, to the influence of the mountainous area orography and, secondly, to the penetration of various air masses. It is observed that in the western part of the basin the average annual precipitation remained almost unchanged over the period 1944-2014, whereas there is a decreasing trend in the eastern part. Assessment of the climate change impact on the formation of the Gunt River water flow was made by comparing the trend in the change of discharge using data from two observation periods 1940-1970 and 1986-2016. Calculations show a decrease of the Gunt River discharge by $5 \%$ over a period of more than 70 years. The influence of climate warming on the river flow is indicated by comparison of river hydrograph in two periods 1940-1970 and 1986-2016. The hydrograph of the Vanch River in the earlier-mentioned periods shows a shift in the maximum of the monthly discharge towards the left, indicating an earlier melting of snow and glaciers in the upstream regions of the river and a significant increase in discharge in the period 1986-2016.
\end{abstract}

\section{Introduction}

Mountain watersheds serve as important water sources by providing fresh water for downstream human activities (Viviroli et al., 2003; Langston et al., 2011). As a result of snow and glacier melt, the magnitude and timing of runoff from these watersheds tend to be very sensitive to changes in the climate (Immerzeel et. al., 2009, 2010, 2012, 2013; Jeelani et al., 2012; Lutz et al., 2014, 2016; Gain et al., 2011). Changes of melt runoff may even affect the sustainable development of downstream cities in the long run (Verbunt et al., 2003; Zhang et al., 2012). Modeling snow and glacier melt runoff processes is therefore quite important for local water supply, hydropower management and flood forecasting (Klok et al., 2001). However, melt runoff modeling in such regions faces two challenges: scarcity of meteorological data and un- certainty in parameters due to limited understanding of the complex hydrological processes.

Growing evidence indicates mountain glacier and snow covered area on average have declined on both hemispheres (IPCC, 2007, 2018). Geographic areas where the water cycle is dominated by snow and glacier melt hydrology in particular expected to be susceptible to climate change as it affects the seasonality of runoff (Adam et al., 2009). Changes in seasonal snow covered and glaciated regions may alter the variability of stream flow and hence water availability that sustains a large population downstream. The reason for the uncertainty is not that people do not understand the regional importance, but it is the complexity of the processes and the terrain that is hard to access to carry out measurements/observations. These climate driven re- 
sponses of mountainous river hydrology may pose significant challenges for this region. Regional climate projections by IPCC (2018) indicate that in Central Asia by the end of the 21 st century the median temperature will rise by of $3.7^{\circ} \mathrm{C}$ with largest warming over higher altitudes particularly in the Tibetan Plateau and the Himalayas (Bhattarail and Regmi, 2011).

As global temperatures rise, the world's snow resources are predicted to change significantly (Hosaka et al., 2005; Christensen et al., 2007; Deser et al., 2010). Long-term changes in global, regional, and local snow depth, snow water equivalent (SWE), and extent will ultimately have major ramifications for ecosystem functions, human utilization of snow resources, and the climate itself through feedback mechanisms like snow albedo (Barry, 1996). Unfortunately, only extent snow cover area (SCA) of the three snow metrics listed above is easily monitored using satellites. This monitoring, which is under way for several decades (Robinson, 1993; Frei anbd Gong, 2005) has shown that global SCA has been decreasing for the past 30 years (Lemke et al., 2007; Matthew et al., 2010).

Snow accumulation generally increases with elevation because of the combined effect of the prevailing lower temperatures and the increased frequency of precipitation events caused by orographic effects.

Distributed data on snow depth, density and snow water equivalent (SWE) with a high spatial and temporal resolution are essential for validation of and/or as input to snow drift models (Prokop et al., 2008) and snow melt

runoff models (Lindström et al., 2010). Thus, there is a great need for distributed snow data, mainly for SWE data (i.e. snow depth and density). Spatially distributed SWE data is important for many stakeholders, for example, it can be used as an input to the new generation of hydrological models predicting snowmelt run-off (Kolberg and Gottschalk, 2006; Udnæs et al., 2007; Arheimer et al., 2008).

Alford and Armstrong (2010) and Alford et al. (2009) examined glaciers and glacier discharge in Nepal zooming in on nine subcatchments of the Ganges left tributaries with a total glaciated area of $3644 \mathrm{~km}^{2}$ and concluded that glaciers contribute by $2 \%-3 \%$ to the discharge of all rivers, flowing from Nepal, i.e., $5.38 \mathrm{~km}^{3}$ in total, which indicates that specific glacier runoff from this area is about $1500 \mathrm{~mm} \mathrm{yr}^{-1}$. In another research, conducted recently in the Nepal Himalaya, the glacier and seasonal snow melt contribution to the Mean Annual Flow (MAF) is estimated as $14 \mathrm{~km}^{3}$, i.e., about $10 \%$ of MAF from Nepal (Andermann et al., 2012).

In the Amu Darya and Syr Darya basins, meltwater contributes by $69 \%$ and $79 \%$, respectively, to mean annual streamflow, and the share of seasonal snowmelt by far outweighs that of glaciers.

The study area includes the climatic zones of the Pamir Mountains. Precipitation and snow depth data from meteorological stations in the relevant climatic zones of the Pamir Mountains were obtained from the Agency for Hydrometeo-
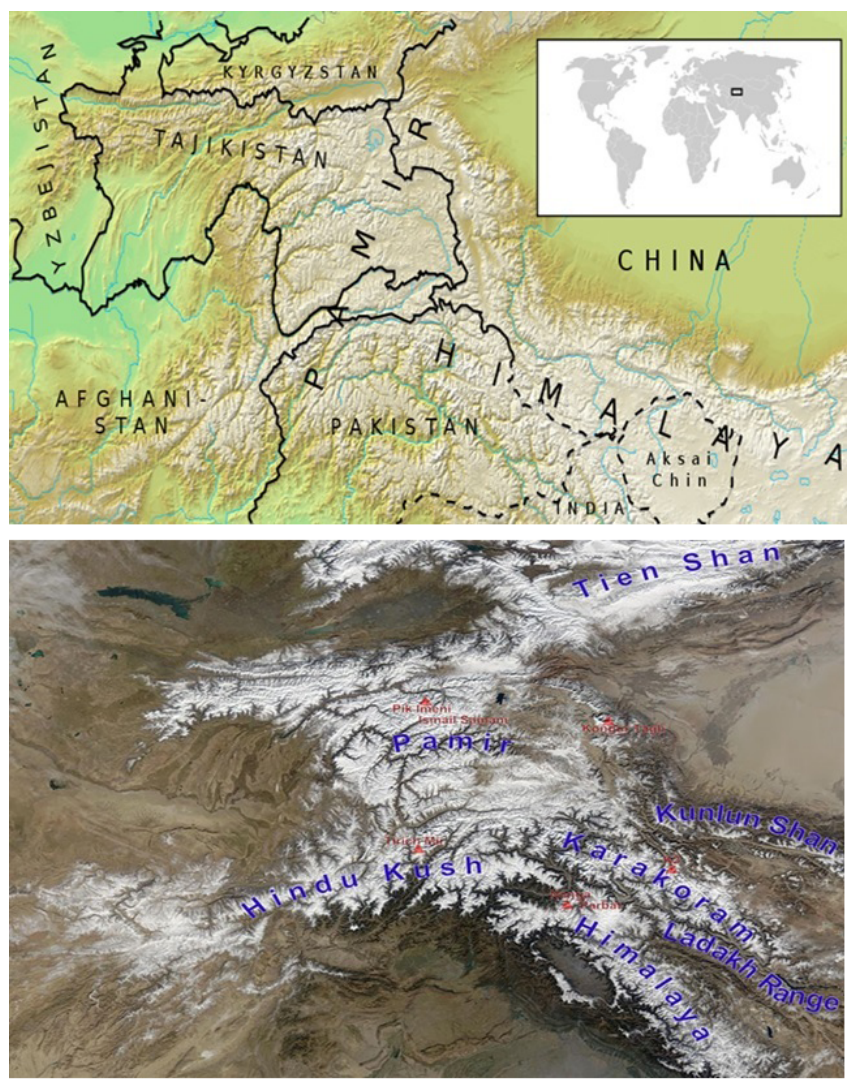

Figure 1. Maps of Mountain Pamir. Sources: (a) https://upload. wikimedia.org/wikipedia/commons/thumb/7/79/Location_map_ Pamir_mhn.svg/1200px-Location_map_Pamir_mhn.svg.png, last access: 12 May 2020, (b) https://upload.wikimedia.org/ wikipedia/commons/thumb/9/9e/High_Asia_Mountain_Ranges. jpg/540px-High_Asia_Mountain_Ranges.jpg, last access: 18 June 2020.

rology of Tajikistan. Mean monthly temperatures and precipitation of the Gunt River Basin were obtained from meteorological stations in the Khorog and Bulunkul regions for the period 1944-2014.

\section{Data and Methodology}

The roof of the World - so often translate the name of the Pamir mountain system. Pamir is located on the territory of Tajikistan, China, Afghanistan and Pakistan and closely connected with other highest mountain systems of the world - Tien Shan, Karakorum, Hindu Kush. Himalayas. In the Pamirs, there are several peaks with a height of more than $7000 \mathrm{~m}$ a.s.l. The highest point of the Pamirs - Kongur peak (7649 m) located in China (Fig. 1).

In Tajikistan, there are such peaks as Ismoili Somoni $(7495 \mathrm{~m})$, Lenin $(7134 \mathrm{~m})$ and Korzhenevskaya $(7105 \mathrm{~m})$. Mountains Pamir is divided into Eastern and Western parts. The Eastern Pamirs in physical and geographical terms is a 
high plateau located above $3500 \mathrm{~m}$ a.s.l. The Western Pamirs is occupied by high mountain ranges separated from each other by deep valleys. The valleys are located at altitudes of $1700-2500 \mathrm{~m}$, and the mountain ranges exceed $5000 \mathrm{~m}$. Glaciers and eternal snow characterize the Western Pamirs. The Pamirs has the largest glaciation with the largest valley glacier Fedchenko (about $70 \mathrm{~km}$ ).

The diversity of climatic conditions in Central Asia, the patterns of changes in meteorological processes, depending on the geographic and geoecological features of the region leads to the need for climatic zoning. The Pamir Mountains is considered to be the area where the influence of moist, cold Mediterranean precipitation decreases and dry Central Asian commences. The main zone of generation of the Pyanj River and its main tributaries Gunt and Vanch rivers water flow is located in the Pamir Mountains (Fig. 2).

The Gunt River is a large tributary of the Transboundary Pyanj River by length of $246 \mathrm{~km}$ and $14840 \mathrm{~km}^{2}$ of the basin area. Its source (Alichur River) originates in the Pamir Highlands, where the river flows through a marshy plain bearing traces of ancient glaciation (Fig. 3). After leaving the lake Yashilkul River is called Gunt. On the stretch from the lake to the mouth, the Gunt flows with a violent rapid current, forming numerous rapids on its way. Before flowing into the Pyanj, Gunt takes on the left a large tributary of the Shakhdarya River (Knowledge Base, 2003).

The Pamir is at the front of the contact between two air masses, the Western (in the winter half-year) and the Indian summer monsoons (in the summer half-year), which dominate in the two climatic zones of the Gorno-Badakhshan Autonomous Region of the Republic of Tajikistan. The Pamir differs from the neighboring Himalayas and Hindu Kush by the fact that the water flow of the formed rivers is mainly determined by the melting of snow and glaciers (Pohl et al., 2015; Fuchs et al., 2013; Aizen et al., 2009; Syed et al., 2006; Palazzi et al., 2013). The Yashilkul Lake on the middle of the Gunt River divides the river basin to the western and eastern parts. The orography of the western and eastern parts of the basin makes a significant contribution to the penetration of air masses and the formation of atmospheric precipitation. A pronounced relief with steep erosional valleys characterizes the western part but the eastern territory is a high plateau with smaller heights and wider valleys. Lake Yashilkul to some extent smooths the average annual value of water consumption and leads to the fact that in low water and in winter the water flow remains almost constant (Meier et al., 2016).

The Gunt River Basin (Fig. 3) is generally located in the transit zone of various air masses, although the formation of a certain amount of atmospheric precipitation in river basin significantly affected by western Indian monsoons and southern cyclones (Meier et al., 2013).

The penetration of air masses from the Mediterranean and Caspian seas is also characteristic of the Vanch River basin. The Vanch River is one of the tributaries of the transboundary Pyanj River that is formed after the confluence of equivalent rivers Kasholyakh and Abdukahor. The river Vanch can be considered a representative of river arteries, in the formation of water flow of which an important place played groundwater, dictated by the geological structure and distribution in the basin of permeable rocks. Measurements carried out in 1965 showed that the annual runoff module in the basin of the Geographical society glacier on the upstream of Vanch River (basin area $206 \mathrm{~km}$, the share of glacial runoff $62 \%$ ) is $15-$ $60 \mathrm{~L} \mathrm{~km}^{2} \mathrm{~s}^{-1}$. In the Abdukahor River Basin on the upstream of Vanch river (the basin area is $329 \mathrm{~km}$, the share of glacial runoff is $42 \%$ ) $28.4 \mathrm{~L} \mathrm{~km}^{2}$ s (Adam et al., 2009). The general tendency reduction of glaciers in Central Asia in the last century also covered the glaciers of the Vanch River Basin. The processing of satellite images LANDSAT ETM+ and TERRA (ASTER) allowed the authors (Prokop et al., 2008; Lindström at al., 2010) to establish that the glacier area of the Vanch river basin for the period 1961-2000 decreased by $23.4 \%$ and throughout the basin of the transboundary Pyanj River by $32.7 \%$.

The territory of the Republic of Tajikistan is characterized by four climatic zones. In turn, the Gorno-Badakhshan Autonomous Region (GBAO) that covers almost the entire mountain Pamir and is a zone of formation of the Transboundary Pyanj River is characterized by three climatic conditions (Fig. 4).

\section{Results and Discussion}

\subsection{Spatial distribution of precipitation and snow cover on the Mountain Pamir climatic zones}

The dependence of the depth of the snow cover and the amount of atmospheric precipitation on the altitude of the mountainous terrain as seen from Fig. 5 does not described by the known regularities.

For example, the meteorological station Shaimak located at an altitude more $3800 \mathrm{~m}$ a.s.l. by the precipitation means differs little from the values typical to the Irkht of meteorological station at the height of $3276 \mathrm{~m}$ a.s.l. The same can be observed at comparison of the snow depth and precipitation values at other meteorological stations.

The spatial heterogeneity of atmospheric precipitation in mountain areas is primarily due to the influence of the terrain orography on the distribution of moist air masses at more moderate altitudes (Darvaz), the average annual temperature increase occurs at a more perceptible rate than at the headwaters (Normatov et al., 2017).

On terraces of the Darvaz meteorological station (1288 m a.s.l.) location the precipitation mostly drops out in the liquid state and seldom observed precipitation in the solid state (under a favorable temperature condition) characterized by short lifetime.

The vertical gradient at the Southern and Central zones borders is about $40 \mathrm{~mm}(100 \mathrm{~m})^{-1}$ of elevation that indicates the more humid foothills and the existence of hallway to pen- 


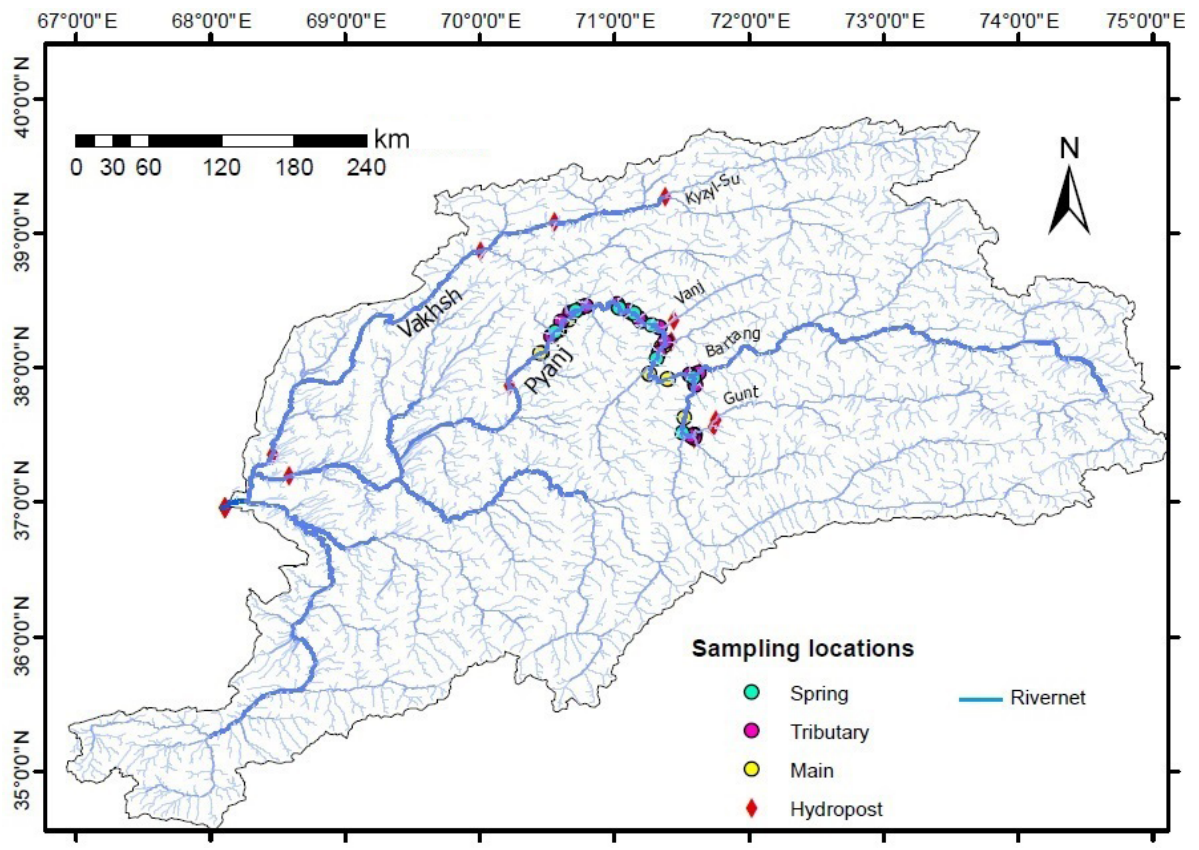

Figure 2. Maps of Pyanj River and tributaries basins.

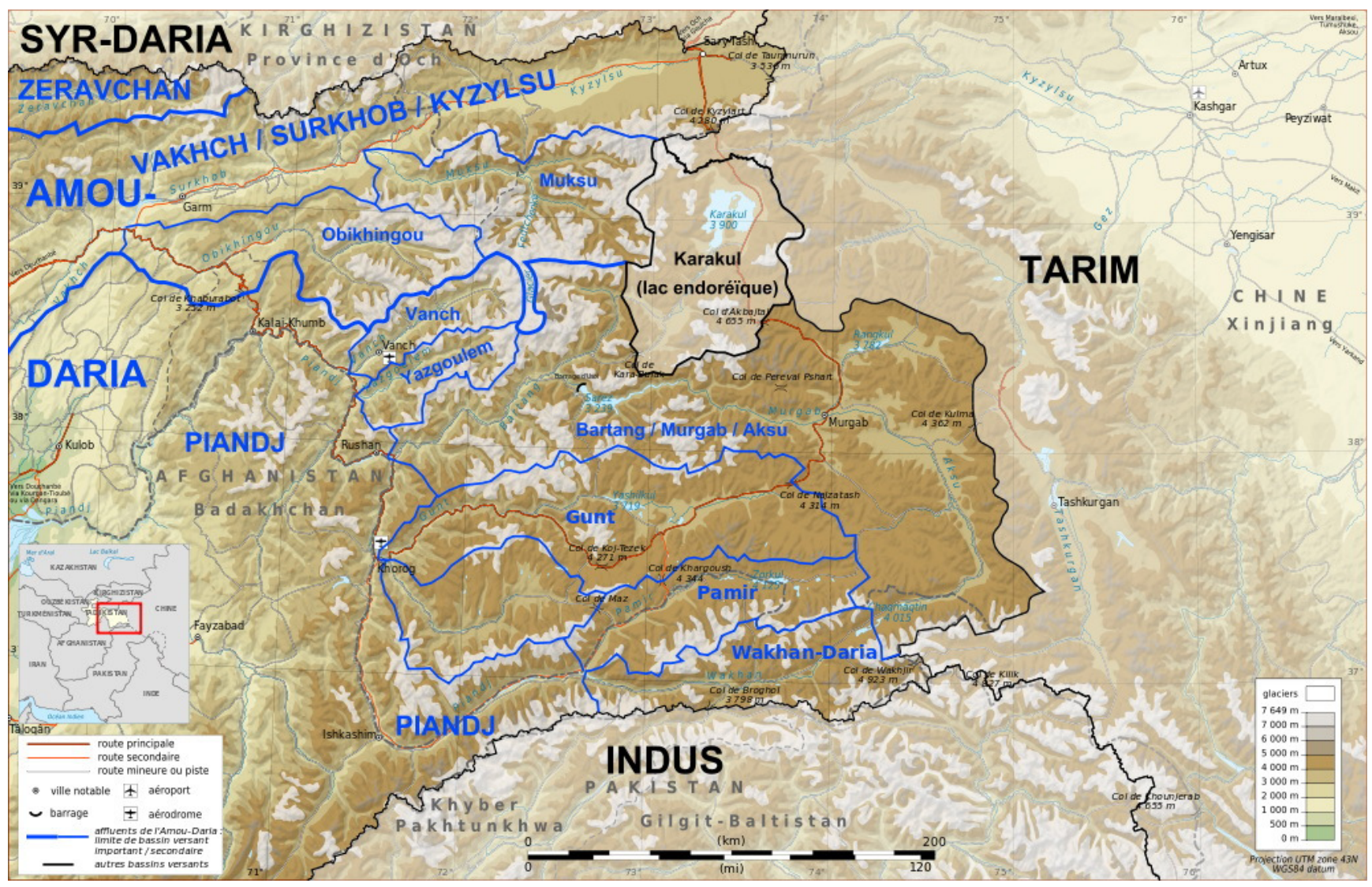

Figure 3. Gunt River Basin on Hydrological Map of the Republic of Tajikistan. Source: https://commons.wikimedia.org/wiki/File:Pamir_ drainage_basin_map-fr.svg, last access: 7 July 2020. 

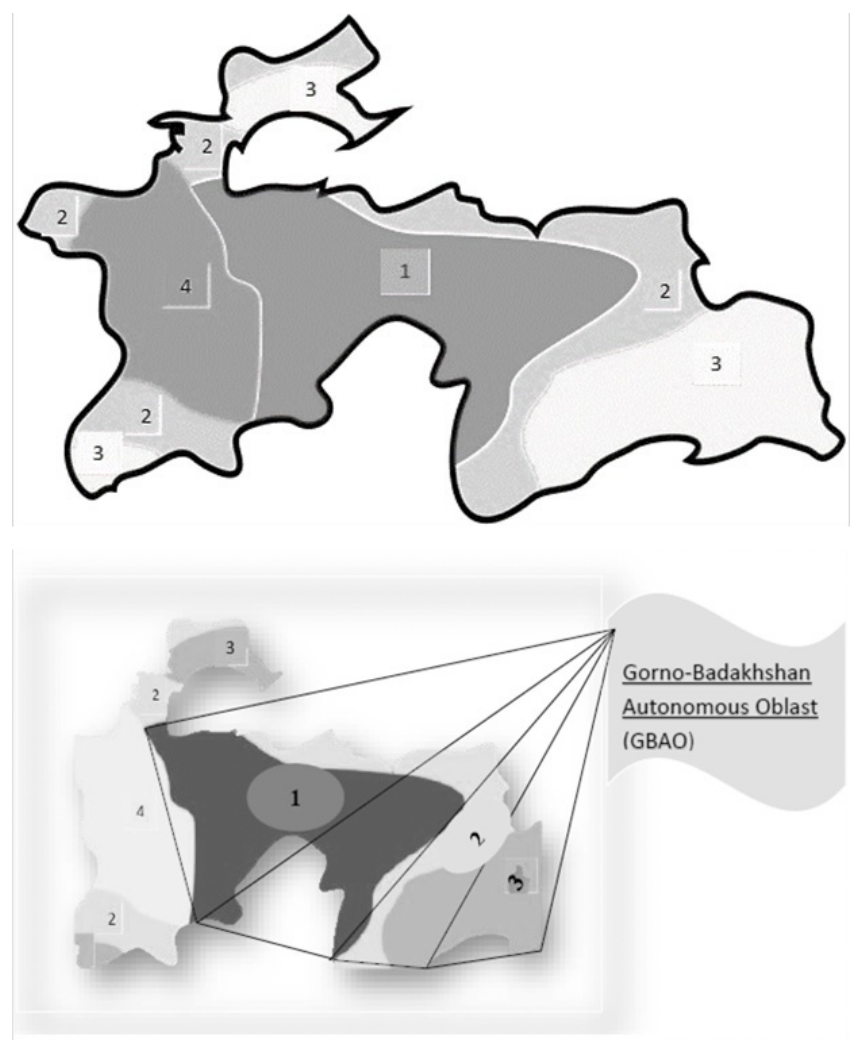

Figure 4. Climatic zones of the Republic of Tajikistan and Gorno Badakhshan Autonomous Oblast: 1 - warm continental climate; 2 - cold semi-arid climate; 3 - dry cold climate; 4 - warm Mediterranean climate.

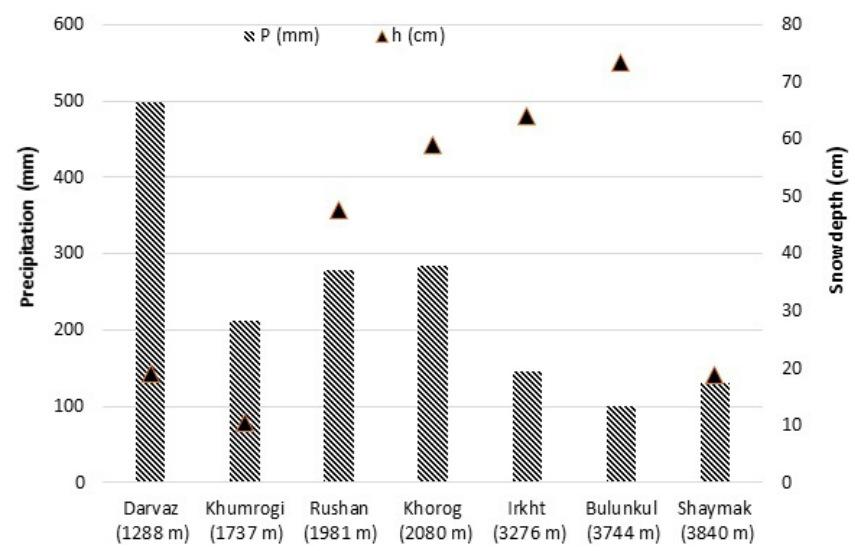

Figure 5. Average annual precipitation and snow depth for seven meteorologica stations in the Pyanj River Basin depending on altitude for the period 1944-2014.

etration of the west humid airflows. As the airflow moves deeper into the mountain range and passes through ridges moist air converts to precipitation and becomes dry.

The average annual precipitation in the Eastern Pamirs is insignificant $(40-140 \mathrm{~mm}$ at average long-term value of about $76 \mathrm{~mm}$ ). Precipitation deficit in the Eastern Pamir is

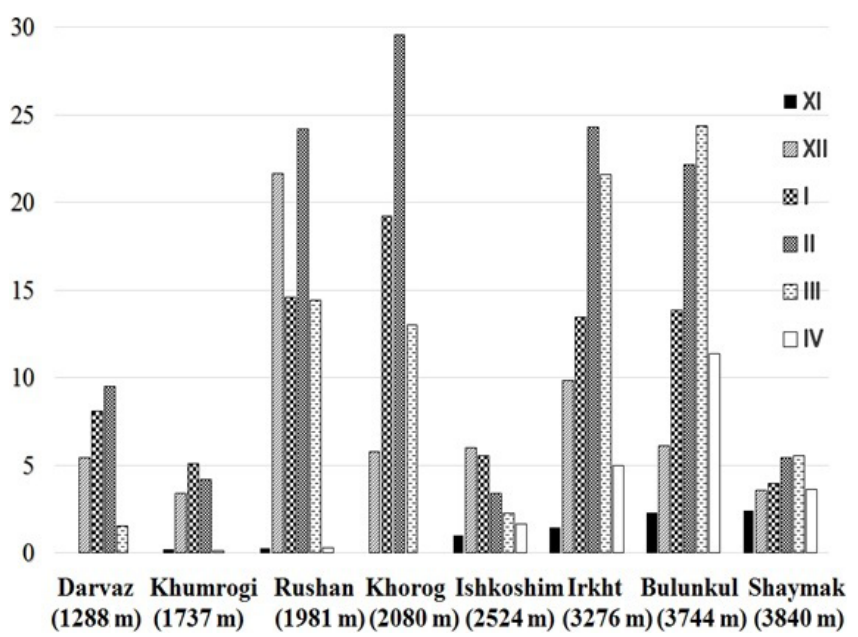

Figure 6. The average long-term monthly snow covers at the meteorological stations of the Pyanj River Basin for the period 19442014.

explained by the fact that in the Western Pamir, characterized by high mountain ranges (5000-6000 $\mathrm{m}$ a.s.l.), there is a discharge of moist air with heavy precipitation and the air passing through its ridges becomes dry (Normatov et al., 2017).

In principle, there should be a time interval between the periods of maximum snowfall in the western, central climatic zone of the Pamir characterized by precipitation that is more abundant and the eastern dry climatic zone. This is primarily because the mass of dry air that crossed the mountain ranges must be saturated by water vapor. The average longterm monthly snow cover at the meteorological stations of the Pyanj river basin as can be seen from the Fig. 6 shows that the maximum value of the snow covers in the eastern meteorological stations Bulunkul and Shaimak corresponds to the March.

The appearance of the maximum value of the snow cover at the Ishkoshim meteorological station in December (Fig. 7) is connect probably by the penetration of air masses from Iran and Afghanistan. At comparing the histograms on the Fig. 6, it becomes clear that the Western and Central climatic zones (Khorog, Irkht, Rushan and Bulunkul) are characterized by a sufficient amount of precipitation and the result of the existence of a temperature regime with a sufficient height of the snow cover.

\subsection{Gunt River Basin Meteorology and Hydrology}

The Gunt river runoff changes and meteorological conditions of the Western and Eastern parts of the Gunt river basin was considered for the period 1944-2016.

The trend of the atmospheric precipitation changes relative to the average long-term for the period 1944-2016 according to Khorog meteostation it shown on the Fig. 8. 


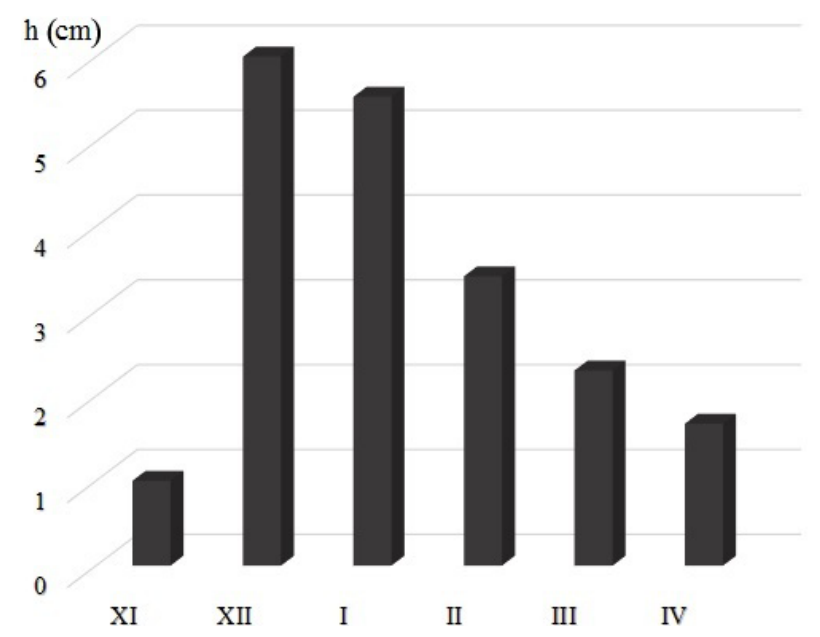

Figure 7. The maximum snow cover at the Ishkoshim meteorological station in the Pyanj river basin for the period 1944-2014.

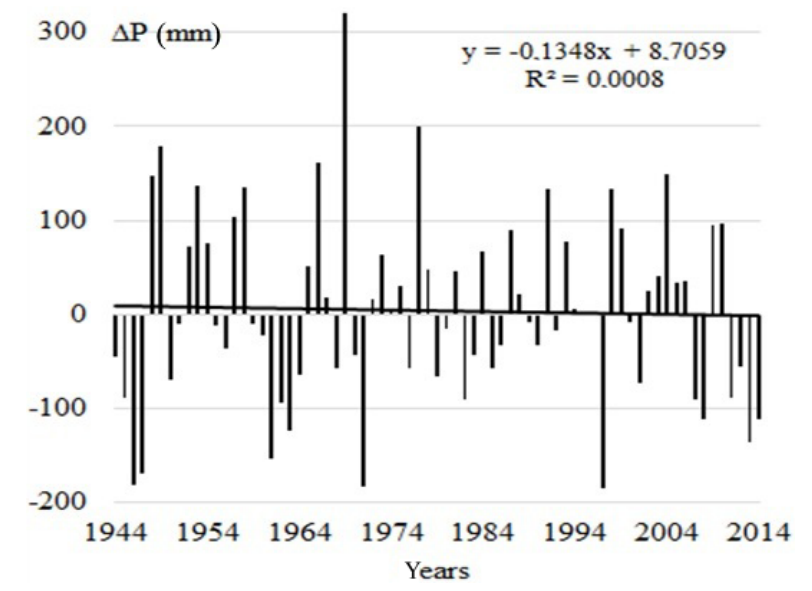

Figure 8. Deviation of annual precipitation from the long-term average (1944-2016) and trend for the Khorog meteorological station.

For more than 70 years (1944-2016), as shown in Fig. 8, precipitation in the Western part of the Gunt river basin was almost constant. However, the temperature increased at a rate of $0.007^{\circ} \mathrm{C} \mathrm{yr}^{-1}$ (Fig. 9). The Middle, North and Caspian Seas air masses penetration to the Gunt River Basin is confirmed by the results of isotope analyzes of the waters of the northern and southern tributaries of the Gunt River (Meier et al., 2016). Despite the small difference in the height of the ridges in the eastern and western parts of the Gunt River Basin rivers is enriched by heavy isotopes. This is primarily due to atmospheric circulation and penetration of the Mediterranean and Caspian cyclones.

An opposite picture of the change in temperature and the amount of atmospheric precipitation in the eastern part of the Gunt river basin was observed (Fig. 10).

The decreasing trend of the atmospheric precipitation and almost constant value of the temperature according on the

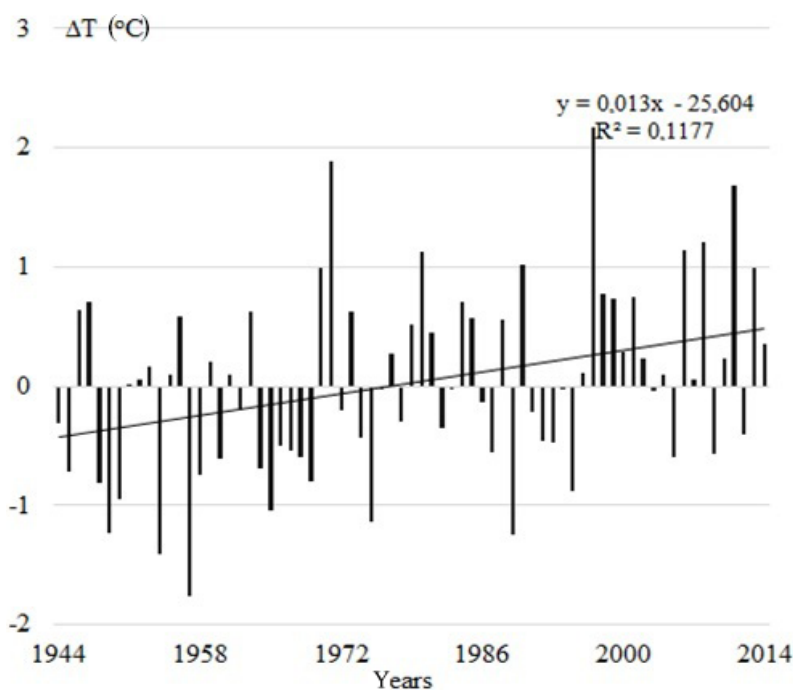

Figure 9. Deviation of annual temperature from the long-term average (1944-2016) and trend for the Khorog meteorological station.

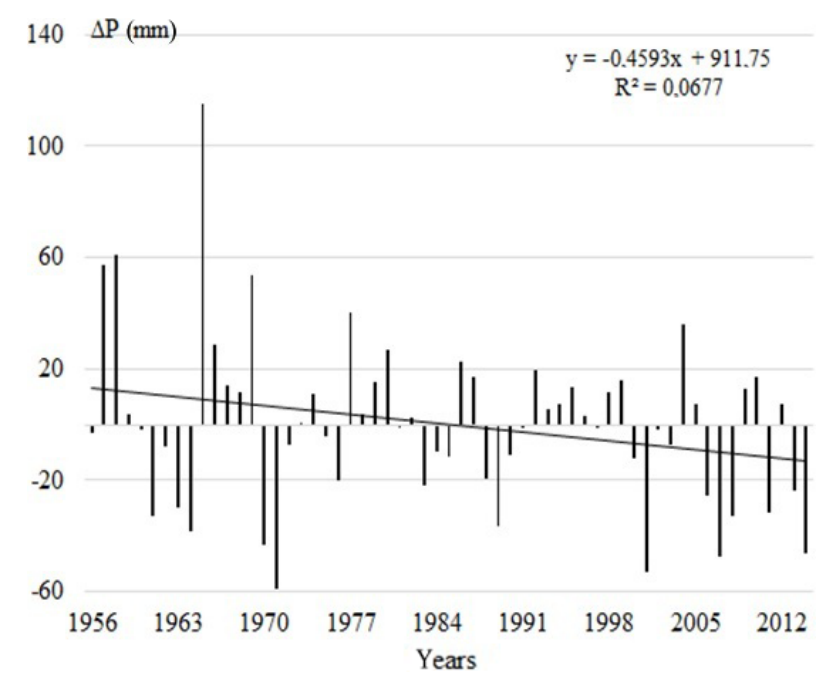

Figure 10. Deviation of annual precipitation from the long-term average (1956-2012) and trend for the Bulunkul meteorological station.

Bulunkul meteostation data for the period 1956-2012 indicates about the influence of the terrain orography on the formation of climatic conditions (Fig. 10). The Western part of the Gunt river basin due to its location, experiences greater and longer solar radiation. Ridges, thereby quickly getting rid of seasonal snow due to the reflection of radiation create an additional thermal effect. Conversely, the processes taking place in the eastern part of the basin, due to the inadequacy of solar radiation, are more conservative. This phenomenon contributes to the fact that the steady-state temperature retains its long-term value (Fig. 11).

The precipitation reducing trend in the eastern part is probably due to the fact that in this part of basin inflow of dry 


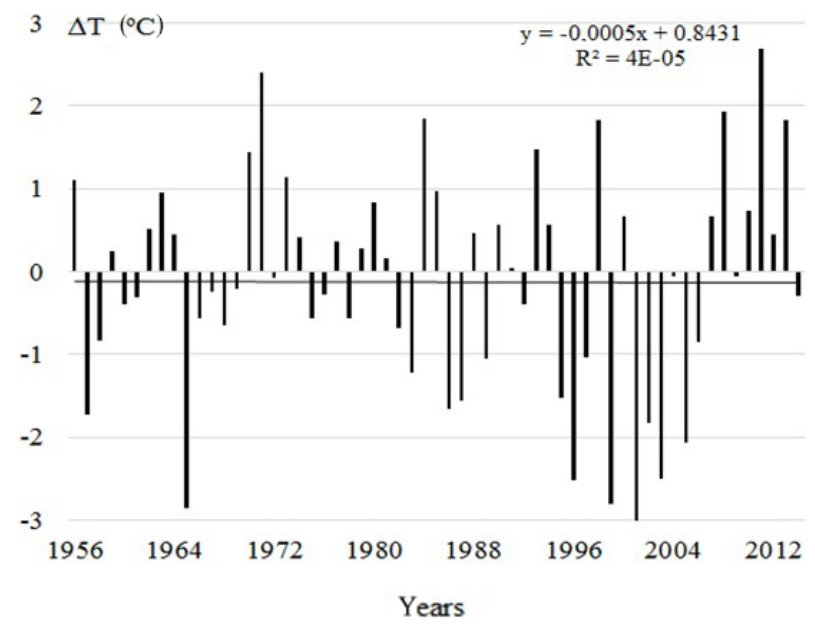

Figure 11. Deviation of annual temperature from the long-term average (1956-2012) and trend for the Bulunkul meteorological station.

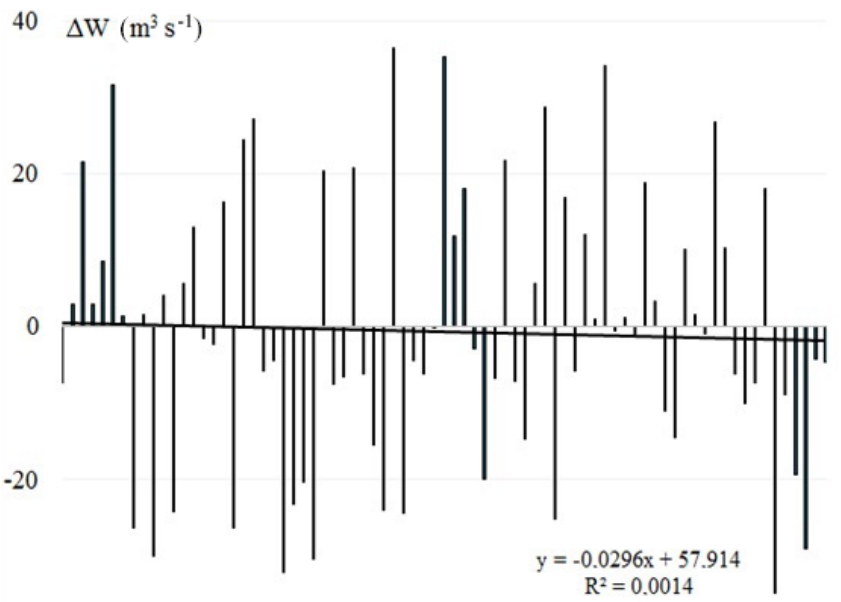

$-40$

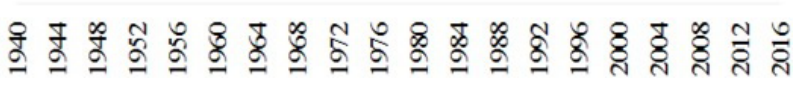

Figure 12. Deviation of annual discharge of the Gunt River from the long-term average (1940-2016) and trend.

mass. The Indian monsoon air mass is unloaded during the passage of high ridges and only the dry residue comes in the eastern part of the Gunt river basin. Naturally, the fluctuation of meteorological parameters cannot but affect the hydrological characteristics of the river system of the basin as well as the Gunt River. Calculations carried out have shown that for more than 70 years the water discharge in the Gunt River has decreased by $5 \%$ (Fig. 12).

To assess the impact of climate change on the Gunt River discharge from the entire spectrum of observations two periods were selected: 1940-1970 and 1986-2016. The river hydrograph for the respective periods is shown on the Fig. 13. The hydrograph of the Gunt River shows that the assumption of the authors (Pohl et al., 2015) on the role of Lake Yashilkul

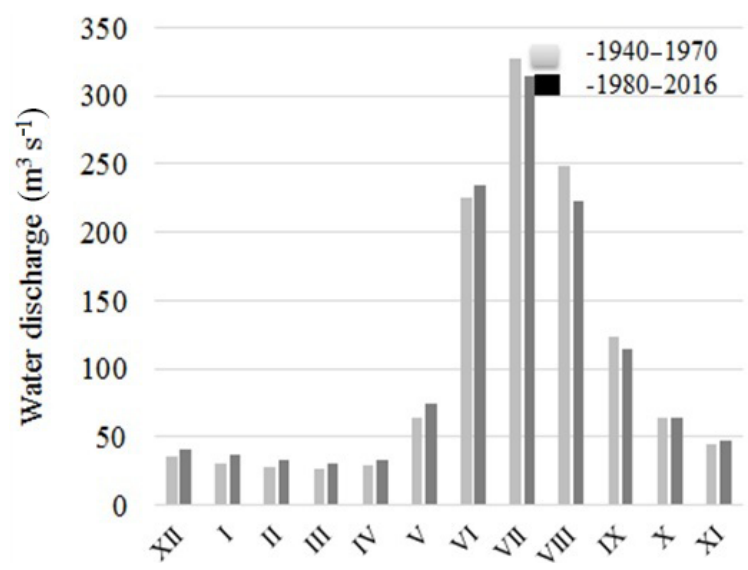

Figure 13. Hydrological regime of the Gunt River for the periods 1940-1970 and 1986-2016.

in smoothing the water level of the river is erroneous since a seasonal distribution of the river runoff is observed.

Calculations to determine the river runoff in the twoselected observation periods show that the volume of runoff in the first and second quarter of the period 1986-2016 is more than their values in the respective quarters of the period 1940-1970. For example, water volume in the first quarter of the period 1986-2016 is more than 19\%, in the second quarter about $12 \%$ more than in the corresponding quarters of the period 1940-1970. Such a picture of the runoff change could be attributed to the climate-warming factor. However, in the third and fourth quarters of the 1940-1970 period water volumes exceed $4 \%$ and more than $2 \%$ of the respective quarters of the period 1986-2016.

The observed phenomena indicate that in the basin of the Gunt river and its tributary (Alichur River) the water supply sources are degraded, which is to reduce the size of glaciers, as well as the contribution of underground sources to the formation of the hydrograph of the winter period of the river.

\subsection{Runoff Formation of the Vanch River Tributary of the Transboundary Pyanj River}

The average annual runoff of the Vanch River in relation to the long-term for the period $1940-2016$ is present on the Fig. 14a.

The period is characterized by an increasing trend of river flow. In order to determine the influence of the climatic factor on the hydrological regime of the Vanch River a comparison of the dynamics of changes in the water flow of the river was made for the periods 1940-1970 and 1986-2016 (Fig. 14b). The hydrograph of the river for two periods (1940-1970, 1986-2016) presented on the Fig. 14b. It can see that the average monthly value of the water flow of the Vanch River for the period 1986-2016 exceeds the analogous values of the period 1940-1970. The nature change of river runoff in two periods indicates about the impact of climate change on 


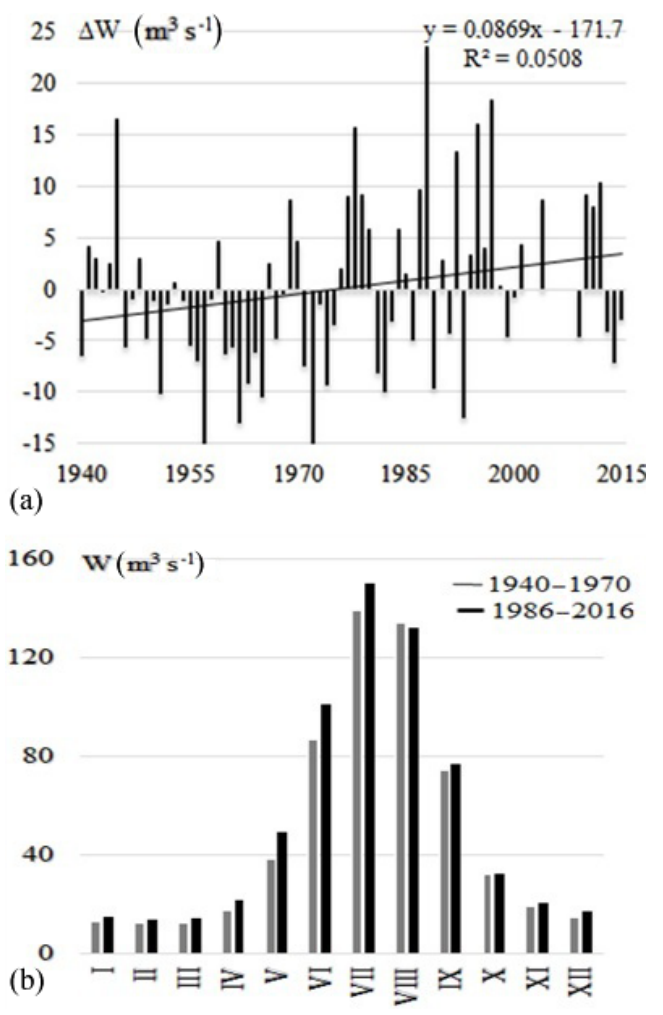

Figure 14. Deviation of annual discharge of the Vanch River from the long-term average (1940-2016) and trend (a), and hydrological regime for the periods 1940-1970 and 1986-2016 (b).

the state of the ice-snow reserves of the basin on the river upstream. If take into account the low temperature changes $\left(3 \times 10^{-3}{ }^{\circ} \mathrm{C} \mathrm{yr}^{-1}\right)$ for considered period, as can be seen from Fig. $15 \mathrm{~b}$ and the almost constant value of atmospheric precipitation (Fig. 15a) then what factors contribute to the positive development trend of the river runoff.

To receive an answer to this question the Vanch River hydrograph make up in the form shown on the Fig. 16a. As can see from the Fig. 16a the maximum of the hydrograph of the Vanch river for the period 1986-2016 is shifted to the left. Therefore, the maximum value of the water runoff is observed earlier than the corresponding value of the period 1940-1970. The observed phenomenon can be explained in the framework of the assumption that the source of the river (glacier) is subject to degradation as a result of warming and is not a dense but loosened structure. For such structures, a small impact is sufficient to effect an aggregate transformation. Based on the obtained results it can be concluded that the glacial area of the Vanch River upstream is subject to a significant reduction. In order to establish the type of supply of the Vanch River it is sufficient to look to the Fig. 14b.

As can be seen from Fig. 14b, the maximum amount of precipitation in the Vanch river basin is March-April but the maximum runoff of the river is July. This means that the Vanch River is characterized by glacier feeding. Naturally,

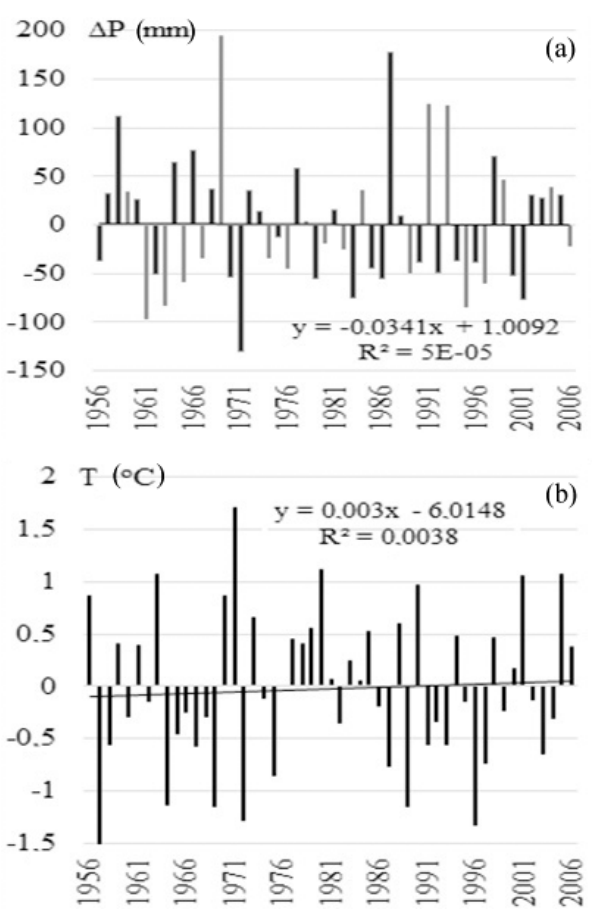

Figure 15. Deviation of annual temperature (a) and atmospheric precipitation (b) from the long-term average of the Vanch River basin for the period 1956-2006.

the contribution of seasonal snows to the formation of the river's water flow is not excluded. The value of water flow observing on the Fig. 16b indicates the predominance of the glacial feeding of the river.

\section{Conclusion}

The spatial distribution of atmospheric precipitation and snow depth in the upstream regions of the Pyanj River, including the Gunt and Vanch Rivers, covering different climatic zones of the Pamir is caused by the orography of the mountainous terrain and irregularities in air mass movements. The western climate zone is characterized by more abundant precipitation than the eastern zone. It is assumed that the duration of snow cover is determined by the temperature regime of the area. Penetration of air masses from the Mediterranean and Caspian Sea to the Gunt River Basin kept the atmospheric precipitation almost constant for more than 70 years in the western part of the river basin. The opposite was found in the eastern part of the Gunt River Basin. It is assumed that the decreasing trend in atmospheric precipitation in the eastern part is because of inflow of dry air mass. The air mass of the Indian monsoon is unloaded during the passage of the high mountain ranges and only dry air enters the eastern part of the Gunt River Basin. Comparison of the hydrological regimes of the Gunt River for the periods 1940-1970 and 1986-2016 shows a change in the seasonal 


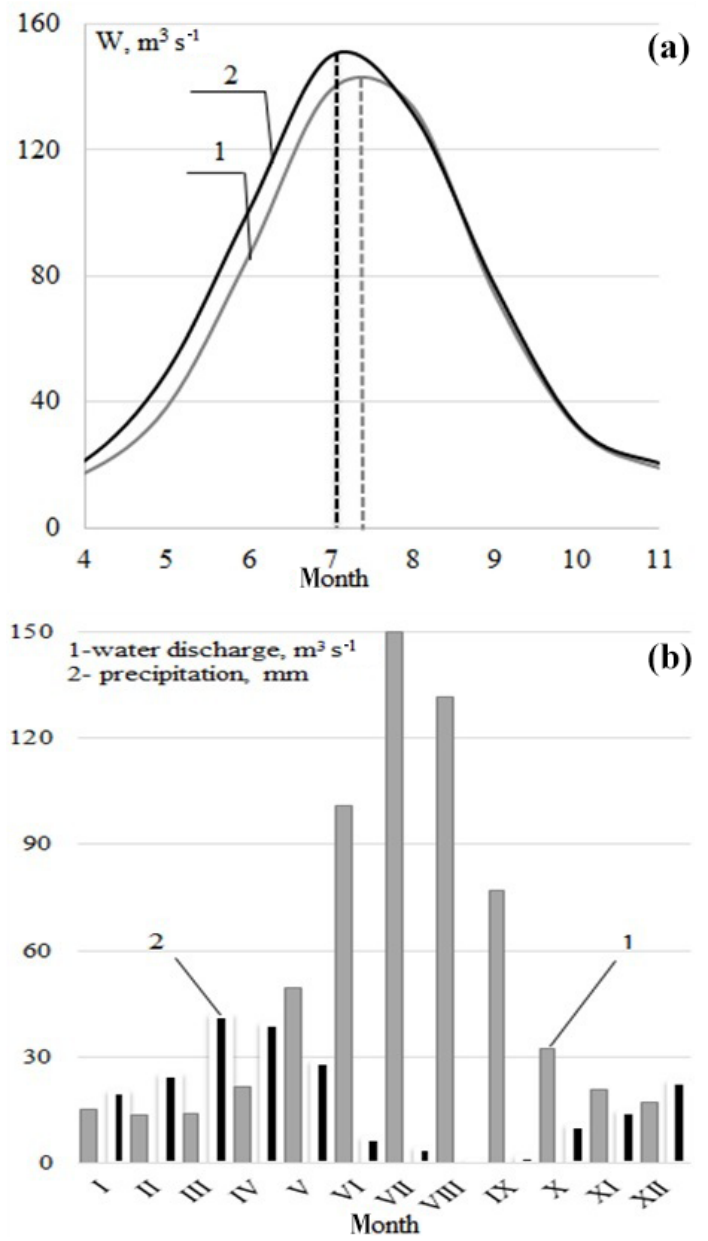

Figure 16. Hydrograph of the Vanch River for the period 19401970 (1), 1986-2016 (2) (a) and the average monthly discharge values of the Vanch River and atmospheric precipitation for the period 1940-2016 (b).

distribution of the river discharge. The change indicates that the Yashilkul Lake lost its influence that earlier smoothed the water level of the Gunt River. In the Vanch River Basin precipitation remained almost constant during the period 19562016, whereas temperature shows a slightly increasing trend. A comparison of the river discharge for the periods 19401970 and 1986-2016 revealed an increase, which is associated with the degradation of the ice sheet in the headwater of the Vanch River Basin.

Data availability. Meteorological, hydrological and other data are supplied by the Agency for Hydrometeorology of the Republic of Tajikistan (http://www.meteo.tj, last access: 18 June 2020).

Author contributions. The contribution of PN to the work consists in the collection, systematization and processing of meteorological data, design of graphic materials and discussion of the re- sults. The contribution of IN is the formulation of the problem, planning of fieldwork, preparation of the manuscript, analysis of literature sources and discussion of the results.

Competing interests. The authors declare that they have no conflict of interest.

Disclaimer. Authors' point of view may differ from that of USAID.

Special issue statement. This article is part of the special issue "Hydrological processes and water security in a changing world". It is a result of the 8th Global FRIEND-Water Conference: Hydrological Processes and Water Security in a Changing World, Beijing, China, 6-9 November 2018.

Financial support. This research has been supported by USAID (PEER project).

\section{References}

Adam, J. C., Hamlet, A. F., and Lettenmaier, D. P.: Implications of global climate change for snowmelt hydrology in the twenty-first century, Hydrol. Process., 23, 962-972, 2009.

Aizen, V. B., Mayewski, P. A., Aizen, E. M., Joswiak, D. R., Surazakov, A. B., Kaspari, S., Grigholm, B., Krachler, M., Handley, M., and Finaev, A.: Stable-isotope and trace element time series from Fedchenko glacier (Pamirs) snow/firn cores, J. Glaciol., 55, 275291, 2009.

Alford, D. and Armstrong, R.: The role of glaciers in stream flow from the Nepal Himalaya, The Cryosphere Discuss., 4, 469-494, https://doi.org/10.5194/tcd-4-469-2010, 2010.

Alford, D., Armstrong, R., and Racoviteanu, A.: Glacier retreat in the Nepal Himalaya. The role of glaciers in the hydrologic regime of the Nepal Himalaya, Technical Report for the World Bank, South Asia Sustainable Development (SASDN), Environment and Water Resources, Unit, World Bank, Kathmandu, Nepal, p. 86, 2009.

Andermann, C., Longuevergne, L., Bonnet, S., Crave, A., Davy, P., and Gloaguen, R.: Impact of transient groundwater storage on the discharge of Himalayan Rivers, Nat. Geosci., 5, 127-131, 2012.

Arheimer, B., Lindström, G., Pers, C., Rosberg, J., and Strömqvist, J.: Development and test of a new Swedish water quality model for small-scale and large-scale applications, Proc. XXV Nordic Hydrol. Conf., 11-13 August 2008, Reykjavik, Iceland, 2008.

Barry, R. G.: The parameterization of surface albedo for sea ice and its snow cover, Prog. Phys. Geogr., 20, 63-79, 1996.

Bhattarail, B. C. and Regmi, D.: Impact of Climate Change on Water Resources in View of Contribution of Runoff Components in Stream Flow: A Case Study from Langtang Basin, Nepal, Hydrol \& Met., 9, 75-84, 2011.

Christensen, J. H., Hewitson, B., Busuioc, A., Chen, X., Gao, I., Held, R., Jones, R. K., Kolli, W. T., Kwon, R., Laprise, V., Magaña Rueda, L., Mearns, C. G., Menéndez, J., Räisänen, A., Rinke, 
A., Sarr, A., and Whetton, P.: Regional Climate Projections. In: Climate Change 2007: Chapter 11. The Physical Science Basis. Contribution of Working Group I to the Fourth Assessment Report of the Intergovernmental Panel on Climate Change, edited by: Solomon, S., Qin, D., Manning, M., Chen, Z., Marquis, M., Averyt, K. B., Tignor, M., and Miller, H. L., Cambridge University Press, Cambridge, UK and New York, NY, USA, 847-940, 2007.

Deser, C., Thomas, R., Alexander, M., and Lawrence, D.: The seasonal atmospheric response to projected Arctic sea ice loss in the late twenty-first century, J. Climate, 23, 333-351, 2010.

Frei, A. and Gong, G.: Decadal to century scale trends in North American snow extent in coupled atmosphere-ocean general circulation models, Geophys. Res. Lett., 32, 235-239, 2005.

Fuchs, M. C., Gloaguen, R., and Pohl, E.: Tectonic and climatic forcing on the Pyanj river system during the Quaternary, Int. J. Earth Sci., 102, 1985-2003, 2013.

Gain, A. K., Immerzeel, W. W., Sperna Weiland, F. C., and Bierkens, M. F. P.: Impact of climate change on the stream flow of the lower Brahmaputra: trends in high and low flows based on discharge-weighted ensemble modelling, Hydrol. Earth Syst. Sci., 15, 1537-1545, https://doi.org/10.5194/hess-15-1537-2011, 2011.

Hosaka, M., Nohara, D., and Kitoh, A.: Changes in snow cover and snow water equivalent due to global warming simulated by a 20 km-mesh global atmospheric model, SOLA, 1, 93-96, 2005.

Immerzeel, W. W., Droogers, P., De Jong, S. M., and Bierkens, M. F. P.: Large-scale monitoring of snow cover and runoff simulation in Himalayan river basins using remote sensing, Remote Sens. Environ., 113, 40-49, 2009.

Immerzeel, W. W., Van Beek, L. P. H., and Bierkens, M. F. P.: Climate change will affect the Asian water towers, Science, 328, 1382-1385, 2010.

Immerzeel, W. W., Van Beek, L. P., Konz, M., Shrestha, A. B., and Bierkens, M. F. P.: Hydrological response to climate change in a glacierized catchment in the Himalayas, Climatic Change, 110, 721-736, https://doi.org/10.1007/s10584-011-0143-4, 2012.

Immerzeel, W. W., Pellicciotti, F., and Bierkens, M. F. P.: Rising river flows throughout the twenty-first century in two Himalayan glacierized watersheds, Nat. Geosci., 6, 742-745, https://doi.org/10.1038/ngeo1896, 2013.

IPCC: Climate change 2007, Synthesis Report, edited by: Pachauri, R. K. and Reisinger A., Geneva, Switzerland, 234 pp., 2007.

IPCC: Summary for Policymakers of IPCC Special Report on Global Warming of $1.5^{\circ} \mathrm{C}$ approved by governments, available at: http://www.ipcc.ch (last access: 24 April 2020), 2018.

Jeelani, G., Feddema, J., Van der Veen, C. J., and Stearns, L.: Role of snow and glacier melt in controlling river hydrology in Liddar watershed (western Himalaya) under current and future climate, Water Res. Res., 1, 48-56, 2012.

Klok, E. J., Jasper, K., Roelofsma, K. P., Gurtz, J., and Badoux, A.: Distributed hydrological modelling of a heavily glaciated Alpine river basin, Hydrolog. Sci., 46, 553-570, 2001.

Knowledge Base: Land and Water Resources Use in the Aral Sea Basin: Rivers, River Systems, available at: http://www. cawater-info.net (last access: 2 March 2019), 2003.

Kolberg, S. A. and Gottschalk, L.: Updating of snow depletion curve with remote sensing data, Hydrol. Process., 20, 23632380, 2006.
Langston, G., Bentley, L. R., Hayashi, M., McClymont, A., and Pidlisecky, A.: Internal structure and hydrological functions of an alpine proglacial moraine, Hydrol. Process., 25, 2967-2982, 2011.

Lemke, P., Ren, J., Alley, R. B., Allison, I., Carrasco, J., Flato, G., Fujii, Y., Kaser, G., Mote, P. W., Thomas, R. H., and Zhang, T.: Observations: Changes in snow, ice and frozen ground, Climate Change 2007: The Physical Sciences Basis, edited by: Solomon, S., Qin, D., Manning, M., Chen, Z., Marquis, M., Averyt, K. B., Tignor, M., and Miller, H. L., Cambridge University Press, Cambridge, UK and New York, NY, USA, 337-383, 2007.

Lindström, G., Pers, C., Rosberg, J., Strömqvist, J., and Arheimer, B.: Development and test of the HYPE (Hydrological Predictions for the Environment) model - a water quality model for different spatial scales, Hydrol. Res., 41, 295-319, 2010.

Lutz, A. F., Immerzeel, W. W., Shrestha, A. B., and Bierkens, M. F. P.: Consistent increase in High Asia's runoff due to increasing glacier melt and precipitation, Nat. Clim. Chang., 4, 587-592, https://doi.org/10.1038/nclimate2237, 2014.

Lutz, A. F., Immerzeel, W. W., Kraaijenbrink, P. D. A., Shrestha, A. B., and Bierkens, M. F. P.: Climate change impacts on the upper Indus hydrology: Sources, shifts and extremes, PLoS One, 9, 1-33, https://doi.org/10.1371/journal.pone.0165630, 2016.

Matthew, S. M., Taras, B., Liston, G. E., Derksen, C., Jonas, T., and Lea, J.: Estimating Snow Water Equivalent Using Snow Depth Data and Climate, Classes, J. Hydrometeorol., 11, 1380-1394, 2010.

Meier, K., Knoche, M., Merz, R., and Weise, S.: Stable isotopes in river waters in the Tajik Pamirs: regional and temporal characteristics, Isotope Envir. Health Study, 49, 542-554, 2013.

Meier, K., Knoche, M., Brehme, M., Merz, R., and Weise, S. M.: Discharge pattern in the Gunt valley, western Pamir, with respect to $\delta^{2} \mathrm{H}, \delta^{18} \mathrm{O}$ and hydrochemistry, in: Chapter 43 . Geostatistical and Geospatial approaches for characterization of Natural resources in the Environment, edited by: Janardhana Raju, N., Springer, New York, USA, Dordrecht, the Netherlands, London, UK, 281-284, 2016.

Normatov, P. I., Markaev, B. A., and Normatov, I. S.: Meteorological Features of Climatic Zones in the Basin of the Transboundary River Pyanj, Bull. Irkutsk St. Univ., 21, 106-113, 2017.

Palazzi, E., Hardenberg, J. V., and Provenzale, A.: Precipitation in the Hindu-Kush Karakoram Himalaya: observations and future scenarios, J. Geophys. Res.-Atmos., 118, 85-100, 2013.

Pohl, E., Knoche, M., Gloaguen, R., Andermann, C., and Krause, P.: Sensitivity analysis and implications for surface processes from a hydrological modelling approach in the Gunt catchment, high Pamir Mountains, Earth Surf. Dynam., 3, 333-362, https://doi.org/10.5194/esurf-3-333-2015, 2015.

Prokop, A., Schirmer, M., Rub, M., and Lehning, M.: A comparison of measurement methods: terrestrial laser scanning, tachymetry and snow probing for the determination of the spatial snow depth distribution on slopes, Ann. Glaciol., 49, 210-216, 2008.

Robinson, D. A.: Hemispheric snow cover from satellites, Ann. Glaciol., 17, 367-371, 1993.

Syed, F. S., Giorgi, F., Pal, J. S., and King, M. P.: Effect of remote forcings on the winter precipitation of central southwest Asia, part 1: observations, Theor. Appl. Climatol., 86, 147-160, 2006. 
Udnæs, H. C., Alfnes, E., and Andreassen, L. M.: Improving runoff modelling using satellite-derived snow covered area, Nord. Hydrol., 38, 21-32, 2007.

Verbunt, M., Gurtz, J., Jasper, K., Lang, H., Warmerdam, P. M. M., and Zappa, M.: The hydrological role of snow and glaciers in alpine river basins and their distributed modeling, J. Hydrol., 282, 36-55, 2003.
Viviroli, D., Weingartner, R., and Messerli, B.: Assessing the hydrological significance of the world's mountains, Mt. Res. Dev., 23, 32-40, 2003.

Zhang, S. Q., Gao, X., Ye, B. S., Zhang, X., and Hagemann, S.: A modified monthly degree-day model for evaluating glacier runoff changes in China Part II: application, Hydrol. Process., 26, 16971706, 2012. 